\title{
NOTES ON SOME EUROPEAN HYMENOPTEROUS PARASITES OF THE HESSIAN-FLY, CECIDOMYIA DESTRUCTOR SAY, AND OTHER INSECTS; BRED BY DR. PAUL MARCHAL, THE FRENCH GQVERNMENT ENTOMOLOGIST.
}

\author{
BY WILLIAM H. ASHMEAD.
}

Assistant Curator, Department of Insects, U. S. National Museum, Washington, D. C.

$$
\text { (Paper No. r.) }
$$

In 1895 and during the year I 896 I received several sendings of most interesting Hymenopterous parasites, for determination, from Dr. Paul Marchal, the well-known French Government entomologist, of the Paris Entomological Station.

All or nearly all of these parasites were bred material and are of great biologic interest, since a few are apparently new to science, and the hosts of many others will now for the first time be made known.

It is important, therefore, on account of the economic importance of many of the species, that the new species be described and that all should be put on record, for the benefit of those interested in these insects.

Below I have therefore given descriptions of the new species, and as briefty as possible, the hosts and relationship of the different parasites.

In recording these rearings by Dr. Marchal, I shall begin with the European parasites bred from the Hessian- fly, Cecidomyia destructor Say, and the Wheat-fly, Cecidomyia avenae Marchal, since these are of the greatest economic importance.

\section{Host I. Cecidomyia destructor Say.}

(1) Boeotomus (Micromelus) rufomaculatus Walk. ㅇ. .

(2) Merisus destructor Say $\delta$ ?

(3) Boeotomus coxalis $\mathrm{n}$. sp.

Winged form. $q$ Length $2 \mathrm{~mm}$. Bronzed green, brighter on mesonotum, the head, thorax beneath and metathorax purplish or blue-green, somewhat coarsely squameously punctate; palpi white; scape of antennae except apically and legs, except coxae, brownish-yellow, knees, tips of tibiae and tarsi, except last joint, and tegulae yellowishwhite; flagellum brown, subclavate, pubescent. Head transverse, wider than the thorax, about $3 \frac{1}{2}$ times as wide as thick anteroposteriorly; eyes rather large oval. Antennae 13 -jointed with 2 minute ring-joints, inserted slightly below the middle of the face, but above an imaginary line drawn from base of eyes; pedicel obconical ; funicle 6jointed, the joints very slightly shortening but also gradually widening to club, the first 
a little longer than thick, the second and third subequal, about as long as thick, the following wider than long; club ovate $3^{-}$ jointed.

Thorax with the pronotum transversely narrowed, the mesonotum a little more than twice as wide as long, with the parapsidal furrows indicated only anteriorly by two short convergent impressed lines which become obsolete at about the middle of the mesonotum; scutellum convex, with the axillae about as wide from each other as their width at base; metathorax produced into a subglobose neck, with curved lateral folds but without a median carina or spiracular furrows, the spiracles small, rounded. Wings hyaline, the nervures pale yellowish, the marginal and postmarginal veins subequal, one-third longer than the stigmal. Abdomen ovate, scarcely as long as the thorax, the second segment (first body segment) occupying two-fifths of its entire length, with a large fovea at base above, the third segment above one-third the length of the second, the fourth, fifth and sixth very short and gradually shortening, the seventh and eighth much longer.

Bred May, I895, from infested stalks of wheat collected March 27 .

\section{Subapterous form.}

8. Length $\mathrm{r} .4 \mathrm{~mm}$. Bronze green, the head in front blue-green; scape and pedicel brownish-yellow, the flagellum filiform, dark brown or brown-black, clothed with a fine pale pubescence; palpi pale; mandibles 4dentate, ferruginous; legs, except coxae, stramineous; coxae metallic; abdomen aeneous black, brassy towards base.

Head and thorax squameously punctate, the head transverse wider than the thorax, about $3 \frac{1}{2}$ times as wide as thick antero-posteriorly, the occiput concave; eyes subovate; antennæ 13 -jointed, with 2 ring-joints, inserted near the middle of the face, the scape about half as long as the flagellum, the ped- icel obconical, a little longer than the ringjoints and the first joint of funicle united, the funicle joints all a little longer than thick, the club ovate, 3 -jointed

Thorax with the parapsidal furrows indicated only anteriorly, the pronotum short, rounded anteriorly; scutellum subconvex, with a subobsolete cross-furrow before apex; metathorax with a subglobose neck, without carinae or spiracular sulci, the spiracles very small. Wings abbreviated, narrowed, not reaching much beyond the middle of the abdomen, the tegulae yellowish. Abdomen broadly oval, polished, impunctate, depressed, wider than thorax and usually but not always truncate at apex, by the retraction of the terminal segments; second segment occupying about half the whole surface or nearly so, the following segments short and gradually shortening toward tip.

Hab. - Poitou and various parts of the Vendée in France.

This has also been bred by Dr. Marchal, from his Cecidomyia (Oligostrophus) avenae, infesting oats.

The species comes nearest to Boeotomus (Merisus) subapterus Riley, but is readily distinguished from it by the metallic coxae, darker flagellum, the longer funicular joints and by its broader more depressed abdomen.

It seems quite distinct from Merisus microptera Lind., Bull. Soc. Imp. Nat. Moscow, I887, p. 182 .

(4) Holcaeus cecidomyiae n. sp.

q. - Length $2.5 \mathrm{~mm}$. Head and thorax olive-green, squameously punctate; scape, trochanters, knees, tibiae and tarsi, except last joint honey-yellow; pedicel bluish; flagellum black, clothed with a short, blackish pubescence; wings hyaline; abdomen aeneous, the large second segment, except the apical margin, blue. 
Head transverse, wider than the thorax, concave behind, about three times as wide as thick antero-posteriorly, the space between the eyes about twice as wide as the eye or a little more than twice the width of the eye; viewed from in front subtriangular; ocelli reddish, subtriangularly arranged. Antennae inserted on the middle of the face, 13 -jointed, with 2 ring-joints, the scape extending to middle ocellus or half as long as the flagellum without the pedicel, the latter obconical, smooth, shorter than the first flagellar joint; flagellum subclavate or gradually incrassated towards tip, clothed with a short rather dense pubescence, the joints delicately fluted, the first joint the longest, less than twice as long as thick, the second a little shorter, the following gradually and imperceptibly shortening so that the last joint is scarcely as long as wide.

Thorax a little more than three times as long as wide at the widest part of the pronotum, rounded anteriorly and with its upper surface narrowed at the middle, the mesonotum as long as wide posteriorly, slightly narrowed anteriorly, with the parapsidal furrows only indicated anteriorly; axillae as wide from each other as their width at base, the scutellum proper convex, longer than wide; metathorax not short, with a distinct median carina, the lateral folds wanting, or at least only indicated by foveae at base, the spiracles not large, rounded, with rather broad sulci behind. Front wings with the nervures pale, the marginal nervure one and a half times as long as the stigmal, or a little longer, the stigmal two-thirds as long as the postmarginal, subclavate, the postmarginal a little shorter than the marginal. Abdomen conic-ovate, as long as the thorax, the second segment the longest, as long as segments 3-5 united, with a large fovea at base above where it unites with the short petiole, and with its posterior margin squarely truncate, segments $3^{-6}$, subequal, the 7 th longer than the foregoing, the 8 th conic.

$\delta$. Coeruleous; tibiae except at both ends embrowned, the scape yellowish beneath, the flagellum long, filiform, with black pile, all the joints long, cylindrical, the first the longest, as long as the scape, or about 7 times as long as thick, the following very gradually shortening; abdomen oblong, nearly linear, with a large oblong, yellow spot on basal third above; otherwise as in female.

This species was bred by Dr. Marchal, in June, 1895 , from Cecidomyia destructor Say attacking stems of wheat.

The species comes evidently nearest to $H$. torymoides Thomson, but is readily separated in the $q$ by color, the shorter abdomen, relative length of the segments and by the length of the flagellar joints, while the $\delta$ is at once distinguished by the very long joints of the flagellum which are clothed with black pile, not white pile as in $H$. torymoides.

(5) Eupelmus

atropurpureus

Dalm. of 9 .

(6) Polygnotus (Platygaster) zosine Walk. $\delta$.

With the above parasites I found also a single male specimen of Isosoma brevicorne Walk.

Dr. Marchal also reports Oscinis pusillus as occurring in the oat stubble.

Host. 2. Cecidomyia avenae Marchal.

(1) Boeotomus coxalis Ashm. $\delta$.

(2) Merisus destructor Say $\delta$ \%

(3) Homoporus luniger Nees $\delta$ o .

(4) Eupelmus atropurpureus Dalm. (=atrocoeruleus Thoms.) 8 \& 9

(5) Eupelmas degeeri Dalm..+ 
(6) Trichacis (Platygaster) remulus Walk. of 9 .

(7) Polygnotus (Platygaster) minutus Lind. $\delta$.

(8) Anaphes pratensis Först. ㅇ. (Egg parasite).

With these were also $\delta q$ specimens of Isosoma brevicorne Walker, which must be a gall-maker on the oats.

Most of the above parasites were bred from their host, occurring in oat stubble, collected in 1894-95, at Poitier and Montreuil. The rearing of Anaphes pratensis Förster, is most interesting, since it is without doubt an egg parasite.

Host. 3. Cecidomyia tritici Kirby.

( I) Merisus destructor Say $\delta$.

\section{DIPTERA FROM THE WHITE SANDS, ON THE TULAROSA PLAINS OF SOUTHERN NEW MEXICO.- I.}

By C. H. TYleR TOWNSEND, LAS CRUCES, N. MEXICO.

The Tularosa plains may be roughly described as lying between the Sacramento Mts. on the east, and the San Andres Mts. on the west, and stretching from the Organ Mts. north to the vicinity of White $\mathrm{Mt}$. They are some 80 miles long, by 30 or 40 wide.

In the northwestern extent of these plains there reposes a reınarkable and extensive surface deposit of disintegraded and weathered gypsum, covering an area some 35 or 40 miles long by an average width of ro miles, and varying in depth from a mere crust to ridges piled up $30 \mathrm{ft}$. above the level of the surrounding plain. This immense deposit is known as the White Sands. The gypsum is pure, without grit, and nearly white, and the banks of it appear from a little distance almost like banks of snow shining in the sun. From the road going up into the Sacramento Mts., in the Rio Tularosa cañon, a splendid view of this gypsum area is obtainable. A view is had at a point some I $200 \mathrm{ft}$. above the plain, and although the spectator is then distant at least 30 miles, the effect is striking in the extreme. The vast stretch of sands lies spread out upon the plain in a panorama of billows, and it is hard to resist the impression that one is looking upon a distant arm of the sea, where a high surf is rolling up upon the sandy beach. The San Andres range, lying close by the western edge of the Sands, enhances the effect, and appears like a rocky promontory washed by the waves. When one comes to walk over the Sands, he finds that the immense

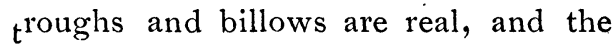
gypsum is seen to assume all the undulations and forms that the winds of the plains are capable of producing.

These Sands are scatteringly covered with a considerable vegetation through- 

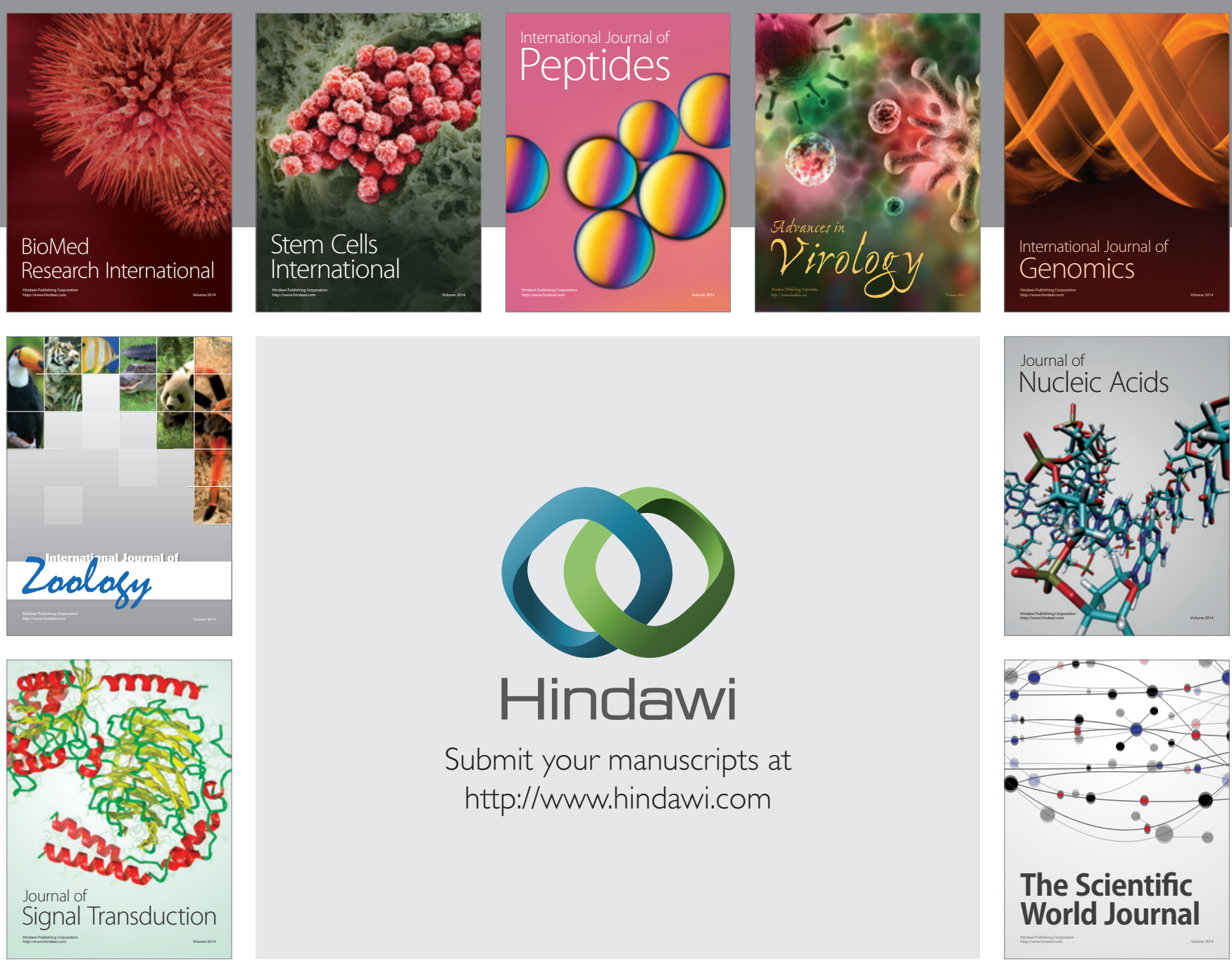

Submit your manuscripts at

http://www.hindawi.com
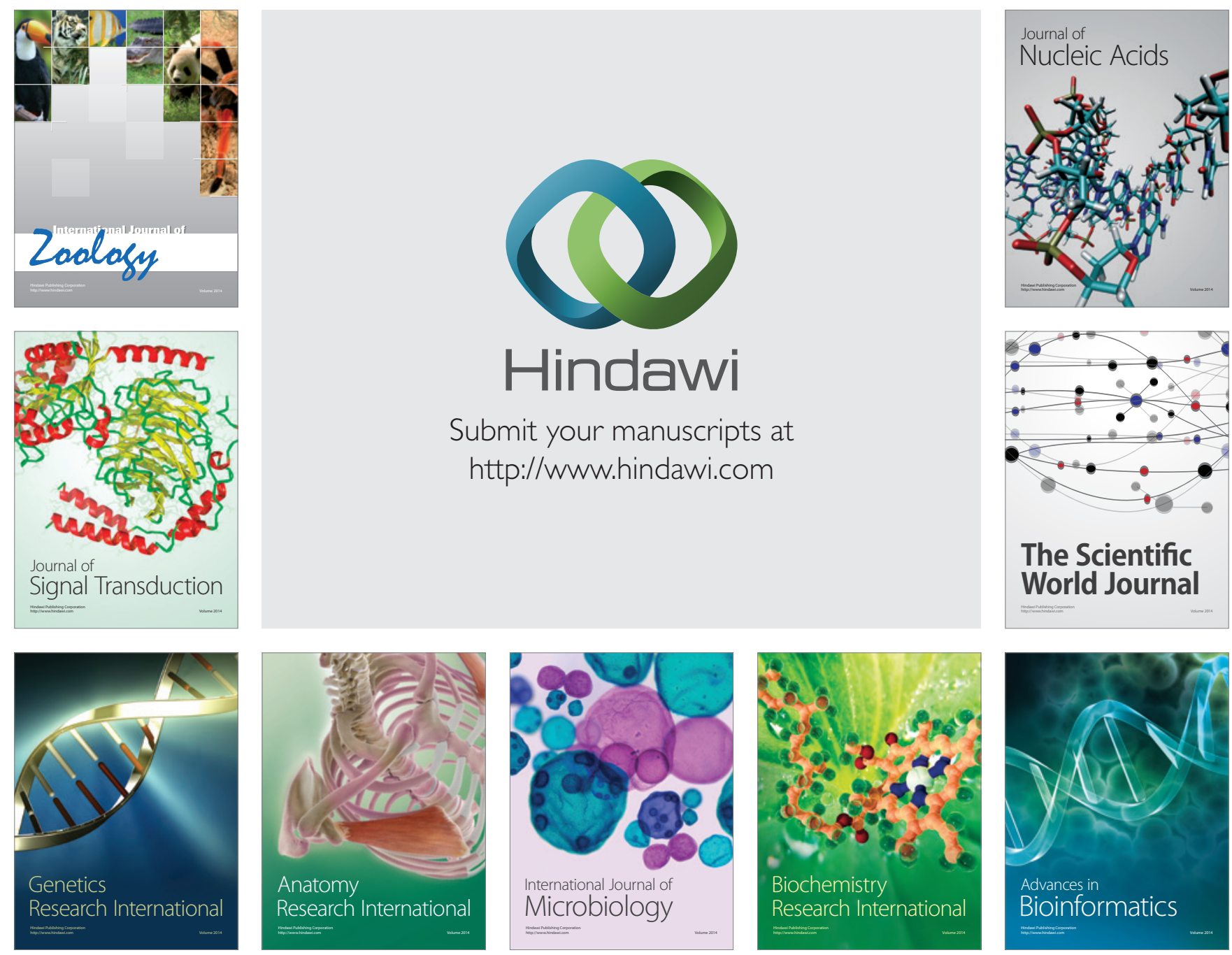

The Scientific World Journal
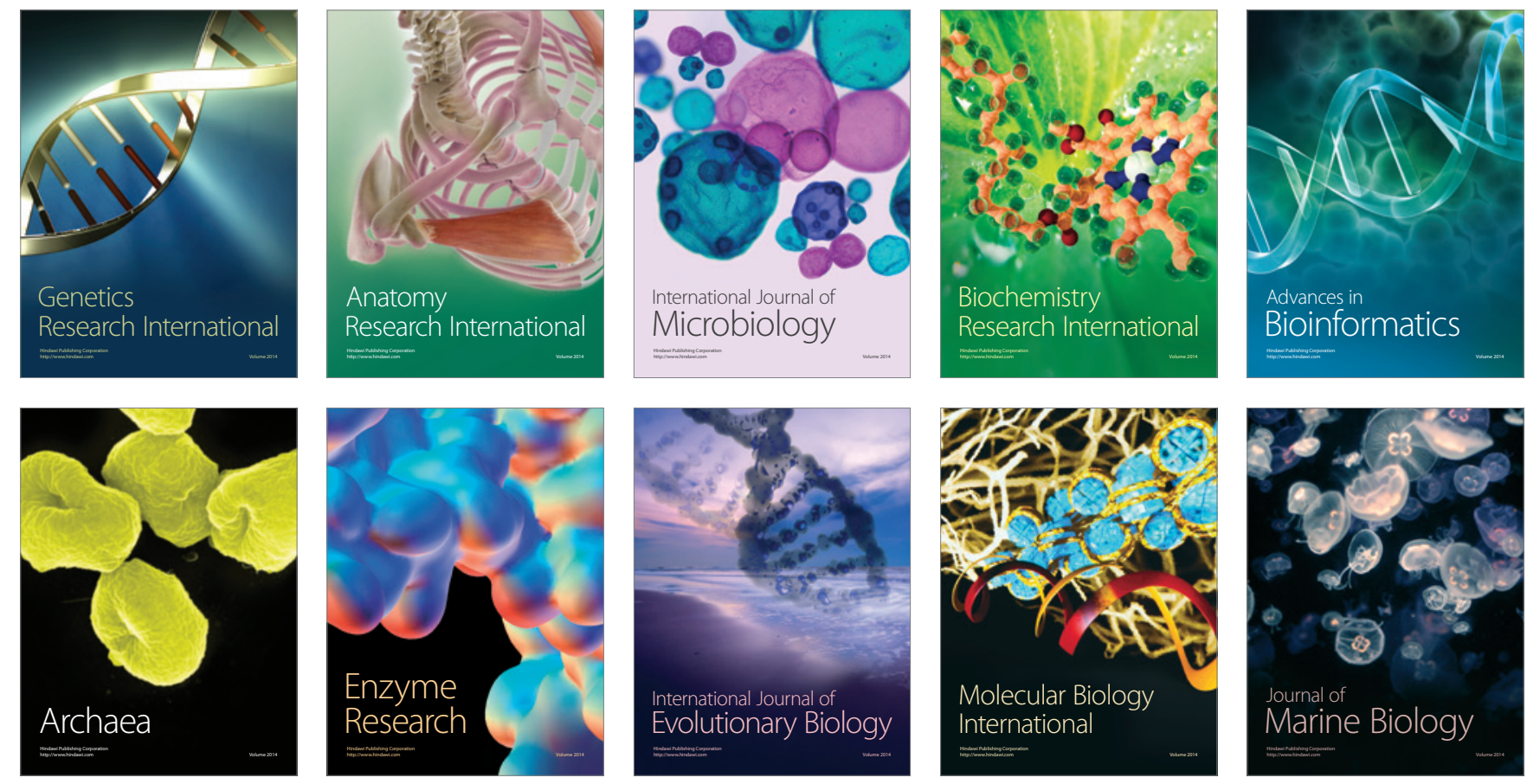